\section{8〜19 世紀におけるイギリススポーツの存在形態}

東京教育大学 浅 朾 隆 夫

1800年までの態様については，拙稿小册子「イギリス における近代市民スポーツを形成する前史」を参昭。こ こでは19世紀だけに限り考察することにしたい。

1800〜'30 年……学校における gentlemansport の同 化と骂校スポーツ，大学スポーツが成立する時期（種日 ・クリケツト，ボート，決斗代用のボクシング，及び比 較们古い学校フットボールなど)

1830〜'50 作……市民スポーツの创始期（クリケット， ボート，陸上:競技)

1850１900年……甫民スポーツの脑大とスポーツ協会 の創設期（クリケット，ボート，クラブフットボール， 陸上競找，クラブホッヶー，スポーツとしてのボクシン ク゚)

要するにクリケット・ボートは，19中紀通じて継続的 な発展を逐げたが，フットボールは，初期の段階を飛び 越えて新しく発展した。

18世紀の patronizing sport は近代 sport ではなか
つたが，新しい精神的身体文化的思想を宿していた。

また，gentlemansportは，身体文化的なるのにだけ は規則的だが，組織的な活動ではなく，同時に民族的活 動す強調され，外部的に当世風で制限された容態をなく していた.

この結果，敛しい分離も職業 sport と gentlemansport との閒には成就しなかつた。

学校 sportは, gentlemansport の模做として始まつ た。しかし細織的な身体教育へと变容していつた。これ は19世紀の 30 年代にその基璴は確立し，次の10年师 には，学校生活のすべての部分に挀大されていつた。

学校 sport の継続は大学 sport であつた。遅くとも 40 年代には，両者は近代 sport へと移行していつた。

組轼の相違は，理念の相違に基ついているが，この理 念によつて sport は，それ独自の発展を逐げていつた。

つまり，近代市民 sport の完成は，1800作のの缡始期 を経て，19世紀にそれぞれ独自の特性に心伈して，継続 的に結热していつたとい方よう。

\section{スポーツの現代化の研究}

\section{一最近の国民体育大会における問通点一}

東京教育大学附属高校 ○中 村 敏 蜼

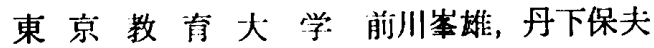

東京教育大学大学院関春南, 早川武意

「国民」体育大会いら名のもとに実施されているスポ 一ッの祭典が，史はその基盤であるところの「国民」か ら極度に遊離している，といらよりはむしろ，国民の希 望と期待に反するすのとしてますます化しつつある といらことは，既に 国民の誰知らぬ者のない束実であ る.

それは岐阜祡の教育長であり，そしてまた選手強化本 部長でもあつた伊藤一郎氏の次の談話によつても明らか である。「本県の現在からみて，一般選手に多くを期待 することはをつかしく，国体優勝のためには，教員選手 と高校生選手に比重がかかるということはさけられない ことです．そこで教育関係の職制を通じて選手強化体制 つくりをしょらといらのが最初のねらいであつた」(「教 育広報」1965．4．15)。

岐皁晾では，国体にそなえて約70名ほどの 教員選手 を採用した。このような新採用の教師をも含む教員選手
たちは，国体前の約1年榈，毎週，土，日，月睢の3日 間を合宿練習で過しており，また火曜から金曜日の午後 を練習にあてている，従つて，授業は火穯から金曜日ま での午能わだけ行なわれるといらことにならさるを得な W.

高校チームもまた，約 1 年間，毎週，士，日矅日は合 宿するか, 楝習試合をするかしており, 中学生選手の越 境入学や想外からの進学者すあつたという。

ここまで追求する時，1万人もいた岐阜県教組の組命 員が 2000 人に激減されていく「教育正常化」問題にふ れないわけにはいかない、それは，人事問題，教育行財 政問題，覀質なデマ，個人攻撃などをからませた組合脱 退屈の提出のみが強要された，体制の側からする組命攻 整であつたといつてよい.

教育関係の「職制」索通じての選手強化が強引に進め られた背景には，このよらな教員の自由と椎利の剝柰が あつたのである。「国民」体有大会は曲り角にきている といわれる。しかし，考方方によれば，すう既に曲り切 つてしまつているといつてよい：これの本質的な変革を 考えない限り，真に「国包的」なスポーツの祭典を箖き 上げることはできない， 